\title{
Enhancing diversity via affirmative action: A case study of the Nelson Mandela Metropolitan Municipality
}

\begin{tabular}{|c|c|}
\hline \multicolumn{2}{|c|}{$\begin{array}{l}\text { Authors: } \\
\text { Ntsikelelo B. Breakfast }{ }^{1} \text { (D) } \\
\text { Brigitte Maart }{ }^{2} \text { (D) }\end{array}$} \\
\hline \multicolumn{2}{|c|}{$\begin{array}{l}\text { Affiliations: } \\
{ }^{1} \text { Department of Political } \\
\text { Science, Faculty of Military } \\
\text { Science, Stellenbosch } \\
\text { University, Saldanha, } \\
\text { South Africa }\end{array}$} \\
\hline \multicolumn{2}{|c|}{$\begin{array}{l}{ }^{2} \text { Department of Public and } \\
\text { Development Management, } \\
\text { Faculty of Military Science, } \\
\text { Stellenbosch University, } \\
\text { Saldanha, South Africa }\end{array}$} \\
\hline \multicolumn{2}{|c|}{$\begin{array}{l}\text { Corresponding author: } \\
\text { Ntsikelelo Breakfast, } \\
\text { nb.breakfast@ma2.sun.ac.za }\end{array}$} \\
\hline \multicolumn{2}{|c|}{$\begin{array}{l}\text { Dates: } \\
\text { Received: } 08 \text { Mar. } 2019 \\
\text { Accepted: } 25 \text { June } 2019 \\
\text { Published: } 27 \text { Aug. } 2019\end{array}$} \\
\hline \multicolumn{2}{|c|}{$\begin{array}{l}\text { How to cite this article: } \\
\text { Breakfast, N.B. \& Maart, B., } \\
\text { 2019, 'Enhancing diversity via } \\
\text { affirmative action: A case } \\
\text { study of the Nelson Mandela } \\
\text { Metropolitan Municipality', } \\
\text { Africa's Public Service } \\
\text { Delivery and Performance } \\
\text { Review 7(1), a275. https:// } \\
\text { doi.org/10.4102/apsdpr. } \\
\text { v7i1.275 }\end{array}$} \\
\hline \multicolumn{2}{|c|}{$\begin{array}{l}\text { Copyright: } \\
\text { ( 2019. The Authors. } \\
\text { Licensee: AOSIS. This wo } \\
\text { is licensed under the } \\
\text { Creative Commons } \\
\text { Attribution License. }\end{array}$} \\
\hline \multicolumn{2}{|l|}{ Read online: } \\
\hline 回保回 & $\begin{array}{l}\text { Scan this QR } \\
\text { code with your } \\
\text { smart phone or } \\
\text { mobile device } \\
\text { to read online. }\end{array}$ \\
\hline
\end{tabular}

Background: This article examines diversity within the context of affirmation action, with specific reference to the Nelson Mandela Metropolitan Municipality. The Employment Equity Act, 1998 (Act 55 of 1998), is a policy instrument through which affirmation action and organisational diversity are promoted in post-apartheid South Africa to increase the economic participation of designated groups.

Aim: Against this background, the aim of this article is to investigate the influence of the Employment Equity Act, 1998, on diversity management in the Nelson Mandela Bay Municipality.

Setting: The guiding research question of this article is: what is the effective way of implementing affirmative action measures through Employment Equity Act, 1998 (Act 55 of 1998), in particular in promoting diversity in the Nelson Mandela Metropolitan Municipality?

Methods: A qualitative approach is employed to explore and describe the complexities at play in this article.

Results: The findings of this article suggest that the goal and vision of diversity management should consistently be communicated in clear terms to all affected, especially the employees as they are most affected by it.

Conclusion: This article contributes to the scholarship of Public Administration and Management surrounding the ongoing debate in South Africa with regard to transformation, organisation diversity and policy implementation of affirmative action. The central thesis of this article is that adequate policy execution of diversity and employment equity will improve service delivery alongside customer satisfaction.

Keywords: Affirmative action; Employment Equity Act, 1998 (Act 55 of 1998); diversity; Nelson Mandela Metropolitan Municipality

\section{Introduction}

Affirmative action as a model of development and transformation to empower the historically marginalised social categories has been rolled out by five countries on a global scale, namely the United States of America (USA), India, Malaysia, Sri Lanka and South Africa (Hermann 2007: 1-24). The list of these countries includes South Africa because affirmative action post-1994 was introduced in 1998 via the Employment Equity Act 55 of 1998. South Africa's model of affirmative action is informed by international best practices and drawn from the experiences of the other countries cited above. Interestingly, in South Africa, affirmative action is geared towards the empowerment of black people who constitute the majority (Breakfast 2013), despite the fact that women and people with disability also fall under the banner of designated groups (Employment Equity Act 55 of 1998). Paradoxically, in the other four countries where the policy of affirmative action is drawn from, empowerment in the workplace is designed to benefit the minority groups who have a history of economic marginalisation. The International Labour Organisation defines affirmative action as a public policy that is meant to address structural inequality by targeting social groups who were sidelined in the past from holding positions of power and decisionmaking in the workforce (Hermann 2007:1-24).

The African National Congress (ANC) believes that affirmative action is a policy for the deracialisation of the economy of South Africa (Breakfast, Chukwuemeka \& Bradshaw 2015: 27-31). This means that this policy is meant to increase the maximum economic participation of 
the historically disadvantaged group. Affirmative action means different things to different people. For policymakers, it means the general elimination of discrimination and the application of the merit principle when making decisions regarding employment. Moreover, affirmative action refers to equal results or the redressing of wrongs caused by the past regime (Nel 1997:9). According to the Employment Equity Act (1998:2), inequality in the labour market in South Africa is created by institutionalisation of racism and the apartheid system of separate development.

Thus, affirmative action was brought to the fore as a public policy. More specifically, the intellectual mainspring for the ANC government affirmative action policy can be found in the policies of the Malaysian majority party, the Bumipetera, after 1969, and the policy adopted by the USA in 1968. In Malaysia, the argument has been made that only the elite have benefited from affirmative action (Pottinger 2008:212). It is worth noting that affirmative action and broad-based black economic empowerment have come under heavy criticism from the official opposition party, namely the Democratic Alliance. Their main line of argument is that these race-inspired policies tend to benefit the middle class and those who are politically connected. The ruling party in South Africa sees affirmative action as a public policy for transformation in both the public and private sectors (Breakfast et al. 2015:27-31).

Both affirmative action and broad-based black economic empowerment are policy instruments meant to correct the historical imbalances of the past. Broad-based Black Economic Empowerment is different from the original Black Economic Empowerment policy. Mbeki (2009:67) states that Black Economic Empowerment was designed by big white-owned companies in South Africa. He concludes by arguing that the main objective of this policy was to co-opt political leaders of liberation movements by actually buying them off with what looked like a transfer of wealth to the majority of the black people. Black Economic Empowerment was introduced as Act 53 of 2003, signed by former President Thabo Mbeki (Balshaw \& Goldberg 2005:65). Black Economic Empowerment was too narrow in its focus and did not encompass the 'codes of good practice' (Balshaw \& Goldberg 2005:65). Over and above that, Black Economic Empowerment was seen by policymakers not to be adequate enough to benefit the majority of the poorest of the poor who are on the margins of the economy. Hence, in 2004, the Department of Trade and Industry introduced the 'codes of good practice', which provided a framework for broad-based black economic empowerment and how it should be implemented. Government had to introduce a scorecard for the implementation of broad-based black economic empowerment (Department of Trade and Industry 2004:3-7).

All the aspects of broad-based black economic empowerment scorecard are regarded as 'codes of good practice'. The codes of good practice encompass:

... employment equity, skills development, preferential procurement, and enterprise development and the status of transformation charters and a framework for BEE rating agencies. The codes are binding on all state public entities; and will be applied in all decisions involving procurement, licensing, concessions, public-private partnership, and the sale of state owned assets. Moreover, no private company can escape the codes because the requirements of the procurement component will cascade down public sector supply chains. (Butler 2009:77)

The ANC government has followed an approach similar to that employed by the Nationalist Party during apartheid. Historically, the Afrikaners wanted to be equal with the English people in South Africa (Breakfast 2013:21). This Afrikaner economic empowerment was on the agenda when the National Party came into power in 1948. Afrikaners were given state contracts and financial assistance to venture into business (Marais 2008:20). The Nationalist government had a strong state that was able to intervene in the economy (especially in the agricultural sector) to assist emerging Afrikaner businesses. This was affirmative action of a sort in the sense that the government clearly had a programme for creating a capitalist and middle class amongst the Afrikaners. State bank accounts were given to an Afrikaner-controlled bank, government tenders were also given to Afrikaner companies and Afrikaners were appointed in upper echelons of the state apparatus as heads of departments (Butler 2009:75-76).

This article examines diversity within the context of affirmation action, with specific reference to the Nelson Mandela Metropolitan Municipality. The Employment Equity Act, 1998 (Act 55 of 1998), is a policy instrument through which affirmation action and organisational diversity are promoted in post-apartheid South Africa to increase the economic participation of designated groups. In this regard, this article attempts to address its main aim, namely to investigate the influence of affirmative action in the light of the Employment Equity Act of 1998 on diversity management in the Nelson Mandela Bay Municipality. The guiding research question of this article is as follows: what is the effective way of implementing affirmative action measures through Employment Equity Act, 1998 (Act 55 of 1998) - in particular, in promoting diversity in the Nelson Mandela Metropolitan Municipality? A qualitative approach is employed to explore and describe the complexities at play in this article. Then the research methodology and design are explained in detail after the literature review. This article contributes to the scholarship of Public Administration and Management surrounding the ongoing debate in South Africa with regard to transformation, organisation diversity and policy implementation of affirmative action. The next section will lay out the literature review.

\section{The theoretical development of diversity}

The concept of diversity had its provenance in the USA in the late 1980s (Johnson \& Packer 1987:81). The large-scale attention to issues of diversity (e.g. race and gender) in organisations had its origins in the passage of legislation requiring equal opportunity for women and racial minorities 
that grew out of the upheavals of the 1960s in the USA and certain parts of Western Europe. Affirmative action was introduced by the end of the 1960s as a legal strategy for handling the racial discrimination observed in companies and educational institutions across the country. Similar developments took place in Britain, which passed the Race Relations Act in 1976 to handle the problems of gender equality and equal employment opportunity (Nkoma \& Stewart 2006:521).

The concept of diversity management traces back to 1987 when the Hudson Institute published its influential report, 'Workforce 2000' (Johnson \& Packer 1987). Diversity management became political 'when its inclusive philosophy was seen as an attractive alternative to affirmative action policies, which were causing widespread unease' (Lorbiecki \& Jack 2000:20). The third period came about when political interest in diversity management turned economic with the introduction of compelling arguments which warned firms that, if they did not pay immediate attention to managing diversity, their organisation's performance or image will be put at risk (Lorbiecki \& Jack 2000:21). The final period began when diversity management turned critical and managers encountered problems in its implementation and diversity.

Diversity management is the process of planning for, organising, directing and supporting a collective mixture of differences and similarities in a way that adds a measurable difference to organisational performance (Hubbard 2004:8). Stockdale and Crosby (2004:12) argue that diversity management is the purposeful use of processes and strategies that make the differences amongst people into an asset rather than a liability for the organisation. Thus, diversity management involves systematic and planned programmes or procedures that are designed (1) to improve interaction amongst diverse people, especially people of different ethnicities, sexes or cultures, and (2) to make this diversity a source of creativity, fuller and greater organisational effectiveness, rather than a source of tension, conflict, miscommunication or a constraint on the effectiveness, progress and satisfaction of employees. Being in compliance with equal opportunity regulations is not enough. Diversity management is a long-term process that demands top management identification and commitment to set in motion a mechanism to access the potential of all employees.

Van der Waldt and Du Toit (1997:260-263) explain that managing diversity within a public institution is a sensitive matter, particularly the management of change in the present South African sociopolitical context. Diversity management refers to those unique human qualities that differentiate one person from another. They further explain that a person is a complex being with unique values and attitudes, different abilities and a unique personality. It is further explained that the management of diversity basically means that the complex and heterogeneous nature of the composition of the public workforce should not be taken for granted, but that the workforce should be formed into a tight unit (Maart 2014:19).
According to Human (1996:80-82), the management of diversity is very complex. Many organisations are currently examining the need to manage diversity better. The management of diversity is closely tied into the effective management of tasks through people and requires a commitment to create an organisation in which the management of people is a major priority. It is not enough for individuals within the organisation to be competent managers of diversity only.

\section{Diversity management in South Africa}

Van der Waldt and Du Toit (1997:260) claim that diversity is a characteristic attribute that is available in all public institutions owing to the heterogeneous composition of the population of South African society. They further explain that public managers should cautiously address the issue of differences in the workplace in order to promote unity and solidarity. Human (1996:46-64) states that very few committed efforts to manage diversity are made, even though the urgency of the matter is realised. She states that the case is often one where either diversity interventions are not incorporated into the overall strategic and human resources processes, or there is a failure to recognise the extent to which affirmative action requires changes in organisational culture and management methods.

According to Kamoche et al. (2004:15), South African managers live in a society rich in diversity. Organisations need to shift from compliance to a commitment model that has an organisational culture reflecting the notion of Ubuntu and capacity building as vital for both competitiveness and equity in the workplace. South Africa faces a double transitional challenge to redress historical inequalities by building a democracy based on human rights and tolerance, while simultaneously and speedily developing its human capacity to compete in a harsh global economy. Although progress has been made to enhance racial and gender diversity, this is an incremental process that has to be supported by coherent human resource development priorities and changes in organisational culture. Managing a diverse workforce is a daunting challenge and, arguably, a bigger policy and practical challenge than managerial and executive employment equity, where the focus seems to lie.

According to Carr-Ruffino (2005:20), it is unfortunate to note that some organisations in South Africa still see managing diversity as part of its employment equity or affirmative action policies. Government initiated affirmative action and employment equity; its efforts were legally driven in order to change the makeup of organisations' employees from a quantitative standpoint. When these prescripts were introduced, the emphasis was on absorbing large numbers of previously disadvantaged people. By contrast, managing diversity is the specific necessity in organisations to drive the efforts of change from a qualitative standpoint and the utilisation of the organisation's workforce, and is neither affirmative action nor employment equity. 
Shonhiwa (2006:11) comes to the fore in stating that it is the 21st century and South Africa is experiencing an enormous challenge. The demographics of the country's workforce have changed dramatically and the new millennium heralds a revolution in the way work will be done to meet the challenge of the 21st century. South Africa must access the best and brightest employees. The workforce must be willing and able to provide the skills and commitment necessary to compete in the world economy. Leaders must emerge from the workplace to motivate and direct the workforce. These leaders must be able to understand the organisations' and the employees' needs and ensure that both are met. If South African organisations are to succeed, the emergence of the diversified workforce must be recognised and the means to harness its energies, talents and differences from tomorrow's challenge must be found. Thomas (2006:97) acknowledges that there are major groups that provide diversity in the workforce - such as ethnic groups, black, mixed-race, Indian or Asian and white people - to complicate the matter further, and more than 11 languages are spoken by these groups.

According to Grobler (2002:50), the reasons why the diversity management programmes in South Africa have not had great success include the following:

- There are no follow-up activities after the initial training phase.

- There are few or no incentives for managers to increase the diversity of their workgroups.

- Top management views diversity as a human resources issue that does not contribute to the organisation's longterm success.

Thomas (1996:48) confirms that there are organisations in South Africa, although very few, that have progressed in this field. Some lessons can be learnt from those that have progressed beyond the so-called formal Affirmative Action stage and have gone on to develop effectively managed diverse workforces. Van der Walt and Du Toit (1997:260-263) explain that the managing of diversity within a public institution is a sensitive matter, particularly the management of diverse groups. Much progress has also been made in some government departments with regard to increasing the representation of designated groups (black people, women and persons with disabilities). Many departments have adopted a hiring, transfer, development or promotion process which pro-actively or re-actively attempts to advance candidates from specific target groups (the designated group).

\section{Diversity in public institutions}

According to Wissink, Schwella and Fox (2004:325), many countries in the world, just like South Africa, have undergone economic, political and social changes. These trends have resulted in an increased diversity in national populations and in the workforce employed to deliver services to these populations. Today, managers are challenged by diversity. The way in which diversity is dealt with can have beneficial or detrimental effects for the employees as well as the organisation. A diverse workforce holds many benefits for organisations and diversity management should therefore be a priority within organisations.

According to Swanepoel, Erasmus and Schenk (2008:384), the increasing multinationalism and multiculturalism of workforces pose significant challenges for leaders in South African organisations. It has been emphasised that leadership is important and that the styles, actions, attributes, orientations and approaches of leaders all have a significant effect on workers and, ultimately, on the success of organisations. In South Africa, there are issues and challenges regarding leadership and organisational success. Leaders need to recognise the emergence of the diversified workforce and find the means to harness its energies, talents and differences for tomorrow's challenges.

The United Nations Paper on best practices in diversity management, written by Reichenberg (2001:3), also focuses on the fact that managing a diverse workforce can be a challenge. When people from different backgrounds come together in the workplace, there is potential for great accomplishment, but also for great conflict. Van der Walt and Du Toit (1997:260) claim that diversity is a characteristic attribute that is available in all public institutions owing to the heterogeneous composition of the population of South African society. They further explain that public managers should address the issue of differences in the workplace cautiously in order to promote unity and solidarity. The consequences of the mismanagement of diversity are too obvious to be ignored. In addition, failure to attend to workforce diversity will result in a disconnection of equity and fairness issues from the organisation's bottom line (Ospina 1996:441-459).

Smit and Cronje (2002:268) suggest that successful diversity management depends on the commitment of the whole organisation. Many spheres of management activity are involved in preparing an organisation to accommodate diversity. These include assessment, leadership commitment and diversity in strategic planning, measurement, accountability, employee involvement and training. These are discussed in further detail below.

In order to promote the agenda of transformation in the South African society, the ANC rolled out the affirmation action policy, known as the Employment Equity Act No. 55 of 1998. The rationale behind this policy was to promote deracialisation of employment in the workplace. Both the public and private sectors have to abide by these policy prescriptions in order to promote the conception of diversity. According to the Employment Equity Act, 1998 (1998:18), affirmative action as a public policy is meant to give employment preferences to those who were historically disadvantaged, marginalised and oppressed. This implies that designated groups who are qualified should be represented in all occupational sectors and spheres of different leadership. Again, members of the designated 
groups as a social category should not be unfairly discriminated against with regard to employment and promotion in the workforce (Employment Equity Act 55, 1998:18).

The Constitution of the Republic of South Africa, Act 108 of 1996 (section 9), prohibits the practice of unfair discrimination against anyone. Amongst other things, this includes discriminating against people on the basis of race, physical disabilities, ethnicity, personal views, ideological dispossession, cultural practice, sexual orientation and gender categorisation (Employment Equity Act 55, 1998:18). However, it must be noted that affirmative action alongside the Employment Equity Act, in the Constitution of the Republic of South Africa, Act 108 of 1996 (section 9, subsection 5), is referred to as fair discrimination. This implies that the Constitution of the Republic of South Africa gives credence to and validates the Employment Equity Act 55 of 1998. This means that the South African Constitution is interpreted by judges or the court of law in a historical context. This is done to acknowledge the social injustices, dehumanisation and human rights violation of the designated groups. The next section outlines a detailed discussion on the research methodology or design of this article.

\section{Research methodology and design}

This article employs a qualitative research approach because this study is descriptive and exploratory in its design. According to Fox and Bayat (2007:7), qualitative research methods are designed to scientifically explain events, people and matters associated with them and do not depend on numerical data, although they may use quantitative methods and techniques. Some of its usual topics are case studies, grounded theory (building theory from the ground up) and ethnography (scientific description of the different human races). It is worth noting that data collection was carried out between 2015 and 2018 in the Nelson Mandela Metropolitan Municipality.

To analyse the managing of diversity within the Nelson Mandela Bay Municipality, a qualitative research approach was considered. Study participants were purposively selected. The sample for this article consists of 10 respondents comprising the head of the Department of Employment Equity, human resources manager, three senior human resources officers and five human resources officials. The selection of these participants was conducted on the basis of their direct decision-making ability and their ability to drive change.

Purposive sampling is one type of non-probability sampling which was used for this study. The advantage of using purposive sampling is, according to Leedy and Ormrod (2001:218), that it makes no pretence of identifying a representative subset of a population. It takes people or other units that are readily available, for instance those that arrive on the scene by mere happenstance.
For the purpose of this article, semi-structured in-depth interviews and document analysis were used to gather data on diversity management practice because the aim was to investigate the managing of diversity. The purpose of the semi-structured interview and document analysis for this study was to explore the views, experiences, beliefs and/or motivations of individuals on specific matters (Gill et al. 2008:291-295). Again, interviews and document analysis were used and during the interviews, audio recordings were used to ensure that data were preserved for transcription purposes. Data were securely stored on a personal computer with the use of password protection and transcription documents were labelled in an anonymous manner to ensure the confidentiality of the data.

A thematic analysis was used to analyse empirical data. This implies that data analysis and interpretation are presented in themes and participants are quoted verbatim. Therefore, the use of ATLAS.ti is also employed to identify themes when pursuing thematic analysis. Babbie and Mouton (2005:337) state that the ATLAS.ti software enables its users to easily group and manipulate codes as well as to create a 'network view' option that indicates the relationship between codes; this software was selected for use during the data analysis phase. Amongst other things, the researchers in this article have analysed and interpreted key strategic documents of the Nelson Mandela Bay Municipality, namely Nelson Mandela Bay Metropolitan Municipality Draft Integrated Development Plan 2011-2016, the Nelson Mandela Metropolitan Municipality Employment Equity Plan (2002/2006), Policy Document for People with Disabilities in the Nelson Mandela Metropolitan Municipality (Incorporating the Metro Integrated Disability Strategy, 2007) as well as the Nelson Mandela Metropolitan Municipality Gender and Women Empowerment Policy Document (2007). This article has adhered to all the ethical requirements of the scientific community, namely keeping the names of the participants anonymous. The data collected were kept confidential until this article was written. It must be borne in mind that data collected for this paper will not cause any harm to the participants. The next section discusses the findings of this paper critically.

\section{Data analysis and interpretation Theme: Diversity management}

Participants were asked to respond to the following question: in your opinion what are the most significant contributory factors for effective diversity management in the light of Employment Equity Act of 1998? To uphold the anonymity of the responses, in the presentation and analysis of results, participants will be referred to as participants 1, 2, 3, 4, 5, 6 and 7:

Employee buy-in is key to effective diversity management, at all levels. Without acceptance of diversity within the municipality, any policy introduced to enhance diversity will be met with scepticism. (Participant 4, male, head of the Department of Employment Equity) 
This point is also stressed by Gibbons (2006) when he asserts that:

Employee buy-in, or employee engagement, is a heightened emotional connection that an employee feels for his or her organisation, which influences him or her to exert greater discretionary effort to his or her work. (p. 4)

Management should be trained, with the mandate to cascade the information within the municipality. Training should therefore be made available to employees directly and not just to management levels. (Participant 5, female, Human Resources Manager)

\section{Discussion}

Leadership from a strategic point of view is another contributing factor to diversity management. The focus should first be on implementing training and transformation, but can then shift to diversity training with specific reference to relationships between different groups within the municipality. Therefore, proper communication between leaders and employers should promote diversity within the leadership of the municipality. Again, employee buy-in is key to effective diversity management at all levels, and that without acceptance of diversity, no policy will be met with scepticism. Continued awareness and management support are also key to ensure that effective diversity management is not only implemented but also maintained.

\section{Theme: Diversity measures/quality of services}

The participants were asked how diversity management contributes to the quality of service and productivity of the municipality. For reliability purposes, they were further asked what measures they use to manage diversity in the municipality.

Various responses were given as follows:

Participant 7 said that:

$[D]$ iversity does contribute to the quality of services and productivity of the municipality because, through diversity, you are bringing differing minds together which will encourage debate and will, at the end, improve the service rendered because it will be an inclusive agreement where all possible spheres and people's concerns should have been addressed orderly. (Participant 7, female, senior Human Resource Officer)

\section{Participant 2 agreed that:}

$[D]$ iversity management contributes to the quality of service and productivity, because it is through the diversity of the country's population, as well as the demographic and cultural differences within each region, that quality of service can be adequately addressed through effective diversity management. Also, productivity levels are enhanced through a motivated workforce which is complemented by effective diversity management. (Participant 2, male, senior Human Resource Officer)

Diversity management does contribute to the quality of services and productivity; the participant proposes that by having a diverse group of employees, they'll be able to relate to one another and to the community. Diversity Policy has just been adopted and not yet implemented within the municipality. Diverse people have different cultural practices; training is thus important in order for employees to understand and respect each other's cultural practices and space. (Participant 3, female, Human Resource Official)

It was established during the interviews that the Diversity Management Policy has not yet been implemented; it has only been adopted within the municipality even though most respondents agreed that diversity contributes to the quality of service and productivity in the municipality. The assumption is made that those who agreed that diversity could contribute to the quality of services made this claim based on their knowledge of the concept and what they anticipate would be the case when the Diversity Management Policy is implemented. Before any measures can be suggested on how diversity should be managed, it is important that the Diversity Management Policy should be implemented, put into practice and exercised, monitored and implemented.

\section{Document analysis phase}

This phase of data analysis and interpretation presents the findings of municipal documents which relate to diversity. The documents which were analysed are Nelson Mandela Metropolitan Municipality Employment Equity Plan (2002/2006), Policy Document for People with Disabilities in the Nelson Mandela Metropolitan Municipality (Incorporating the Metro Integrated Disability Strategy, 2007), as well as the Nelson Mandela Metropolitan Municipality Gender and Women Empowerment Policy Document (2007).

The Nelson Mandela Metropolitan Municipality Employment Equity Plan (2002/2006) reflects upon the primary areas of the course of action to follow. It presents proposals that will ensure that the workforce of the Nelson Mandela Bay Municipality will be more reflective of the demographics of the municipality within 5 years. The Nelson Mandela Bay Municipality, namely the Nelson Mandela Metropolitan Municipality Employment Equity Plan (2002/2006), requires that all employees should be made aware and informed of the content and application of the Employment Equity Act, 1988 (Act 55 of 1988), in preparation for their participation and consultation:

- Employment Equity and anti-discrimination issues

- The proposal process to be followed by the employers

- The advantages to employees of participation in the process

- The need for the involvement of all stakeholders in order to achieve a positive outcome (Nelson Mandela Metropolitan Municipality Employment Equity Plan 2002/2006:14).

Therefore, the municipality's primary aim is committed to employing, empowering and developing competent people 
with the necessary potential required in order to expand their careers and to become valuable participants in sustaining the municipality's service to the local community and act as a development agent (Nelson Mandela Metropolitan Municipality Employment Equity Plan 2002/2006:14). From the municipality's primary aim, one can infer that if the municipality commits to employ, empower and develop competent people, as stated, it will benefit the municipality's strategic planning, accountability, measurement and evaluation; this will link diversity to organisational goals that can be seen as indicators of effective diversity management within the municipality.

The 1997 White Paper on Human Resource Management in the Public Service (1997) provides the following definition of equity:

Where there has been unfairness, corrective measures must be implemented so as to ensure that human resource practices are free from discrimination, invisible barriers and unjustness which will impede equal employment opportunities. (p. 16)

The application of corrective measures seems to be closely related to the concept of equity, which refers to employment equity as something to be achieved through affirmative action programmes, which should be fair and equitable and harness societal diversity (Wessels 2005:129-130). This is underscored by the Conceptual Framework for Affirmative Action and the Management of Diversity in the Public Service (1998:51) as employment equity that can be achieved through affirmative action programmes to accelerate the advancement of designated groups towards the achievement of equality.

The human resource vision of the Nelson Mandela Bay Municipality is that all commanders, managers and human resource functionaries should competently manage their human resources, which is aligned with the 1997 White Paper on Human Resource Management in the Public Service (Republic of South Africa 1997:3.1.4). This White Paper states that all objectives should be in line and human resource managers are jointly responsible for the effective management of the institution's human resources. The Nelson Mandela Metropolitan Municipality Employment Equity Plan (2002/2006) consists of eight objectives, which include the following:

- Promote the Constitutional right to equality.

- Give effect to all labour legislation, in particular the Employment Equity Act and Skills Development Act.

- Give effect to the mission, transformation, vision and strategic plan of the Nelson Mandela Bay Municipality.

- Give effect to the policy on the promotion of equality, diversity and the elimination of unfair discrimination.

- Promote employee participation through the involvement of employees and their trade union representatives, as well as other stakeholders in the development and monitoring of employment equity.

- Ensure the implementation of affirmative action measures to redress the effects of discrimination.
- Achieve a diverse workforce broadly representative of the demographics of the Nelson Mandela Bay Municipality - especially at top management and middle management level.

- Promote economic development and efficiency in the workforce of the Nelson Mandela Bay Municipality.

It is apparent that the municipality is committed to promote equity principles within the municipality. If these objectives are properly implemented, the municipality will be able to unleash diverse skills and knowledge from all its employees. In turn, greater productivity will result from employee job satisfaction and the growth in employment opportunities, social upliftment and improved quality of life, social equity as well as peaceful co-existence that will be achieved. Thus, the municipality will improve the quality of its services. It will also promote effective diversity management in mutual trust and stimulate a good foundation for teamwork.

\section{Diverse workforce}

Despite having all these objectives put in place, the primary goal of the municipality is to ensure that transformation and its developmental role are paramount. Thus, the seventh objective, which indicates that the Nelson Mandela Bay Municipality should have a diverse workforce, is integral to this end; the seventh objective states that to achieve a diverse workforce, levels of top management and middle management should always achieve representation.

The population framework in the Nelson Mandela Metropolitan Municipality Equity Plan (2002/2006) indicates otherwise than what is stated in the objectives.

Table 1 shows the population of the municipality in the Nelson Mandela Bay Municipality. Black people (56\%) followed by mixed-race people $(45 \%)$ are the majority of population in the municipality, and white people $(18 \%)$ and Asian people (2\%) represent the minority. Given this state of affairs, one would expect this to be reflected in the decisionmaking positions of the municipality. On the contrary, Table 2 reflects the opposite.

Van der Walt and Du Toit (2005:159) postulate that top management is responsible for the management of the institution in totality, including strategic management. This entails, amongst other things, a mission, strategy and aims, the compiling of strategic plans and organisation structures, control and decision-making. Middle management is

TABLE 1: Population of the municipality in the Nelson Mandela Bay Municipality.

\begin{tabular}{lc}
\hline Race & $\mathbf{\%}$ \\
\hline Black people & 56 \\
White people & 18 \\
Mixed-race people & 24 \\
Asian people & 2 \\
\hline
\end{tabular}

Source: Adapted from Nelson Mandela Bay Metropolitan Municipality, n.d., Nelson Mandela Bay Metropolitan Municipality Employment Equity Plan: March 2002/2006, p. 7, Nelson Bay Metropolitan Municipality Employment Equity Plan: March 2002/2006, p. 7, Nelson
Mandela Bay Metropolitan Municipality: Port Elizabeth | Uitenhage | Dispatch, Port Mlizabeth, viewed n.d., from http://www.nelsonmandelabay.gov.za/datarepository/documents/ Kfuid_NMBM $\% 20$ Equity\%20plan.pdf 
TABLE 2: Top management profile, middle management profile and support staff profile.

\begin{tabular}{lccc}
\hline Race & $\begin{array}{c}\text { Top management } \\
\text { profile (\%) }\end{array}$ & $\begin{array}{c}\text { Middle management } \\
\text { profile (\%) }\end{array}$ & $\begin{array}{c}\text { Support staff } \\
\text { profile (\%) }\end{array}$ \\
\hline White people & 81 & 68 & 15 \\
Black people & 9 & 14 & 66 \\
Mixed-race people & 8 & 14 & 17 \\
Asian people & 2 & 2 & 3 \\
\hline
\end{tabular}

Source: Adapted from Nelson Mandela Bay Metropolitan Municipality, n.d., Nelson Mandela Bay Metropolitan Municipality Employment Equity Plan: March 2002/2006, p. 8, Nelson Mandela Bay Metropolitan Municipality: Port Elizabeth | Uitenhage | Dispatch, Por Elizabeth, viewed n.d., from http://www.nelsonmandelabay.gov.za/datarepository/documents/ Kfuid_NMBM $\% 20$ Equity\%20plan.pdf

responsible for the tactical management of the institution. They should ensure that policy is implemented and the aims of the institution are achieved. Low-level management is responsible for the operational management of smaller divisions in the institution. They are also responsible for the implementation of objectives set by the middle management.

The demographic employment profile, as shown in Table 2, of the Nelson Mandela Bay Municipality is admittedly a complex matter, as it involves issues of race, specifically at top level. Admittedly, the minority group (18\%, as shown in Table 1) in the population will make decisions on what should be done, that is, determining policies to address the needs of the total majority of $80 \%$ (56\% black people and $24 \%$ mixed-race people).

In addition to the information provided in Table 2, Table 3 shows that males (92\%) are in the majority in top management, with only $8 \%$ of its members being females and $0.25 \%$ of top management being disabled people.

Although the black people reflect the majority of the municipality's employees, as indicated in Table 1, they only constitute $9 \%$ of the top management and they are in the majority $(66 \%)$ at the lower levels of the hierarchy. The mixedrace people, in Table 1, are the second largest population with $24 \%$, indicating $17 \%$ in the lower levels of the hierarchy. However, both black people and mixed-race people constitute $14 \%$ of middle management. White people are in the minority $(18 \%)$ in the population, whereas they are in the majority $81 \%$ at top management, $68 \%$ at middle management and they are in the minority at the lower levels of the hierarchy.

In summary, Tables 1 and 2 present the population employed within the municipality as well as its top management profile, middle management profile and support staff profile. Looking at the figures shown in these tables, it can be inferred that although the majority consists of black people (56\%), only a few $(9 \%)$ are evident within top management. White people, who make up $18 \%$ of the population within the municipality, fill more than half of the positions in top management. Mixed-race people, who comprise $24 \%$ of the municipal population, actually constitute a small portion of (28\%) top management.

At least at middle management level, black people and mixed-race people share the percentage $(14 \%)$, leaving the white population in control with $8 \%$. Within the context of
TABLE 3: Percentage of top management.

\begin{tabular}{lc}
\hline Variable & \% \\
\hline White people & 81.00 \\
Black people & 9.00 \\
Mixed-race people & 8.00 \\
Asian people & 2.00 \\
Females & 8.00 \\
Males & 92.00 \\
Disabled & 0.25 \\
\hline
\end{tabular}

Source: Adapted from Nelson Mandela Bay Metropolitan Municipality, n.d., Nelson Mandela Bay Metropolitan Municipality Employment Equity Plan: March 2002/2006, p. 7, Nelson Mandela Bay Metropolitan Municipality: Port Elizabeth | Uitenhage | Dispatch, Por Elizabeth, viewed n.d., from http://www.nelsonmandelabay.gov.za/datarepository/documents/ Elizabeth, viewed n.d., from http://ww
Kfuid_NMBM\%20Equity\%20plan.pdf

the management profile of the Nelson Mandela Bay Municipality, the philosophy of Total Quality Management should be implemented to ensure high-quality services despite the disparities that exist in the management profile.

According to the Nelson Mandela Metropolitan Municipality Employment Equity Plan, their aim is to employ the suitable person for a job with the necessary formal qualifications, prior learning, relevant experience and capacity to acquire, within reasonable time, the ability to do the job.

\section{Gender representation}

According to Pesonen, Tienari and Vanhala (2009:4), gender is an activity and a social dynamic rather than a role; therefore, gender equity is about exploring how gender figures in social interaction by means of silencing, marginalising and excluding women from positions of influence. Nelen and Hondeghem (2000:17) concur with this view, claiming that gender comprises sociological and cultural differences between men and women, which have been learnt and changed over time and which have different meanings both within and between cultures.

Nelson Mandela Bay Municipality identified five strategic objectives within the Nelson Mandela Metropolitan Municipality Gender and Women Empowerment Policy Document (2007) that would aid its transformation to a nonsexist, non-racist and non-discriminatory institution. These include ensuring that the rights of women and men are equally upheld and that women are enabled to exercise their rights over their bodies and are protected from violence; to ensure that gender needs, priorities and differences are considered and institutionalised in the Nelson Mandela Bay Municipality's policies and practices including its Integrated Development Plan (IDP); to confront the social and ideological barriers to women's participation and encourage initiatives to improve their status, including basic rights. Furthermore, it seeks to develop positive action that will promote the full participation and empowerment of women in existing and future programmes so as to ensure that the Nelson Mandela Bay Municipality's programmes and projects benefit men and women equally and to promote women's access to key resources (e.g. employment opportunities, especially in decision-making positions and start-up capital for business), services and facilities. Therefore, 
TABLE 4: Gender of the study population.

\begin{tabular}{lc}
\hline Gender & $\boldsymbol{\%}$ \\
\hline Female & 8.00 \\
Male & 92.00 \\
Disabled & 0.25 \\
\hline
\end{tabular}

Source: Adapted from Nelson Mandela Bay Metropolitan Municipality, n.d., Nelson Mandela Bay Metropolitan Municipality Employment Equity Plan: March 2002/2006, p. 8, Nelson Mandela Bay Metropolitan Municipality: Port Elizabeth | Uitenhage | Dispatch, Por Elizabeth, viewed n.d., from http://www.nelsonmandelabay.gov.za/datarepository/documents/ Kfuid_NMBM\%20Equity\%20plan.pdf

equality consists of the rights and freedoms of employees, as contemplated in the 1996 Constitution, and includes juristic (equal before the law) as well as equality outcomes. This means that the Nelson Mandela Bay Municipality has to deploy its entire workforce optimally and cannot exclude women and minority groups when the battle for talent in South Africa, which is in the midst of a skills crisis, is fierce (Van Dijk 2008:398-399).

The Nelson Mandela Bay Municipality has an estimated population of 1.2 million, of which $52 \%$ are women. Despite being the majority, women continue to be underrepresented in decision-making structures within the municipality. Table 4 shows that only $8 \%$ of women are employed at the municipality, which implies that they are still underrepresented within management positions.

Women are allowed access to the full spectrum of career opportunities (functional disciplines), which include combat mustering (Republic of South Africa 1996b:28).

The data in Table 4 reveal that only $8 \%$ of the female group are represented in the lower management levels, whereas the focus still lies with the male group, which consists of $92 \%$, at management level.

\section{People with disabilities}

The municipality has committed itself to constructively assisting in the implementation of the overarching policies of the national and provincial spheres of governance, at local government level. The introduction of the municipality's Policy for People with Disabilities by People with Disabilities confirms its commitment to bringing about equal human rights in South Africa (Policy Document for People with Disabilities 2007:4). Through its Policy on Disability, the municipality seeks to provide a mechanism for increasing the access of people with disabilities to opportunities at social, political and economic levels and to ensure that people with disabilities are given every opportunity to reach their full potential, both as individuals and as active citizens in the Nelson Mandela Metropolitan area (Policy Document for People with Disabilities 2007:5).

The Policy Document for People with Disabilities (2007) addresses major concerns and issues critical to people with disabilities. Although the needs of disabled people are accurately explained in the policy, the policy also makes clear that the municipality's disabled employees should constitute at least $5 \%$ of its total employee population (Nelson Mandela
Metropolitan Municipality Employment Equity Plan 2002/2006:7-8). As shown in Table 3, the municipality has $0.25 \%$ disabled people in its employment.

According to the Nelson Mandela Metropolitan Municipality Employment Equity Plan (2002/2006:20), managing diversity initiatives (such as auditing employment policies and practices to ensure that they are focused on productivity and that no one is excluded on the basis of race or disability) have not been implemented and are still in progress. This can also explain why many numbers reflect inconsistencies between policy and practice.

However, it is stated in the Nelson Mandela Metropolitan Municipality Employment Equity Plan (2002/2006:41) that there should be no discrimination against women and people with disabilities as far as training is concerned as well as all employees; policies and practices will be audited for unfair discrimination and related barriers that are unjustifiable. This will include the identification and elimination of unfair discrimination on the basis of the factors listed in Section 9 of the Constitution of the Republic of South Africa 1996 and Section 2 of the Labour Relations Act 66 of 1995. These factors include race, gender, sex, ethnic or social origin, colour, sexual orientation, age, disability, religion, political opinion, culture, language, belief, marital status or family responsibility.

\section{Conclusion and policy recommendations}

This article on diversity management through Employment Equity Act 55 of 1998 in the Nelson Mandela Bay Municipality has led to some significant findings. The Nelson Mandela Bay Municipality has put in place various policies (see the section on data analysis and interpretation) in order to achieve diversity management. However, even when these policies are implemented, no tangible results can be witnessed regarding the effectiveness of diversity in the institution. This could be ascribed to the fact that diversity in the Nelson Mandela Bay Municipality is not considered to be contributing to its quality of services. The concept of diversity is at the heart of transformation as promoted by Employment Equity Act 55 of 1998 .

When diversity awareness principles are taken into consideration, the leadership will automatically improve the strategic plan with the goal of effective integration of diversity within the municipality. The goal and vision of diversity management should consistently be communicated in clear terms to all affected, especially the employees as they are most affected by it. In this regard, diversity management will certainly be addressed amongst employees and managers. This will prompt the leadership to take the initiative in creatively dealing with diversity issues. Leadership should generate short-term and achievable goals to become more visible. This will also enable future managers and new employees to effectively deal with diversity from first contact with the Nelson Mandela Bay Municipality. 
Through the commitment by management, keeping in mind the Total Quality Management principles discussed earlier, this article holds a view that the Nelson Mandela Bay Municipality will benefit through the following:

- strengthening the creation of performance amongst employees

- increasing leadership qualities as well as mutual trust (teamwork) that leads to service delivery excellence

- increasing the importance of economic growth towards achieving realistic service delivery

- the need for continuous monitoring and maintaining and enhancing the quality of service delivery.

\section{Acknowledgements Competing interests}

The authors declare that they have no financial or personal relationships that may have inappropriately influenced them in writing this article.

\section{Author's contributions}

This article is written by both authors. N.B.B. did the theoretical aspect and literature review and B.M. conducted the empirical side of the study.

\section{Funding}

This research received no specific grant from any funding agency in the public, commercial, or not-for-profit sectors.

\section{Data availability statement}

Data sharing is not applicable to this article as no new data were created or analysed in this study.

\section{Disclaimer}

The views and opinions expressed in this article are those of the authors and do not necessarily reflect the official policy or position of any affiliated agency of the authors.

\section{References}

Babbie, E. \& Mouton, J., 2005, The practice of social research, South African edn., pp. 337-340, Oxford University Press, Cape Town.

Balshaw, T. \& Goldberg, J., 2005, Cracking broad-based black economic empowerment, Human and Rousseau, Cape Town.

Breakfast, N., Chukwuemeka, O. \& Bradshaw, G., 2014, 'Market Triumphalism at the Buffalo City and Nelson Mandela Metropolitan Municipalities, South Africa', Africa's Public Service Delivery \& Performance Review 2(4), 22-45. https://doi. org/10.4102/apsdpr.v2i4.66

Breakfast, N.B., 2013, 'Market Triumphalism and the South Africa state: A case study of local government in the Eastern Cape', Unpublished PhD thesis, Nelson Mandela Metropolitan University.

Butler, A., 2009, Cyril Ramaphosa, James Currey, Johannesburg.

Carr-Ruffino, N., 2005, Making diversity work, Pearson Education, Upper Saddle River, NJ.

Constitution of the Republic of South Africa, 1996, Act 108 of 1996, Parliament, Pretoria.

Department of Trade and Industry, 2004, The code of good practice on black economic empowerment: Phase one and phase two, The South African Government, Pretoria.
Fox, W. \& Bayat, M.S., 2007, A guide to managing research, Juta, Cape Town.

Gibbons, J.M., 2006, Employee engagement: A review of current research and its implications, The Conference Board Inc., New York.

Gill, P., Stewart, K., Treasure, E. \& Chadwick, B., 2008, 'Methods of data collection in qualitative research in interviews and focus groups', British Journal 204(6) 291-295. https://doi.org/10.1038/bdj.2008.192

Grobler, P.A., 2002, Human resource management in South Africa, Thomson Learning, London.

Hermann, 2007, The naked emperor: Why affirmative action failed, Protea Book House, Pretoria.

Hubbard, E.E., 2004, 'The diversity scorecard: Evaluating the impact of diversity on organisational performance', Heinemann, Oxford.

Human, L., 1996, 'Managing workforce diversity: A critique and example from South Africa', International Journal of Manpower 17(4-5), 46-64. https://doi. org/10.1108/01437729610127659

Johnson, W.B. \& Packer, A.H., 1987, Workforce 2000: Work and workers for the twenty first century, Hudson Institute, Indianapolis, IN.

Kamoche, K.N., Debrah, Y.A., Horwitz, F.M. \& Muuka, G.N., 2004, Managing human resources in Africa, Routledge, London.

Leedy, P.D. \& Ormrod, J.E., 2001, Practical research planning and design, 7th edn., Merril Prentice Hall, Upper Saddle River, NJ.

Lorbiecki, A. \& Jack, G., 2000, 'Critical turns in the evolution of diversity management', British Journal of Management 11, 17-31. https://doi.org/10.1111/14678551.11.s1.3

Maart, B., 2014, 'Managing diversity: A case study of the Nelson Mandela municipality', Unpublished MA thesis, Nelson Mandela Metropolitan University.

Marais, H., 2008, South Africa limits to change the political economy of transition, Revised and expanded new edn., University of Cape Town Press, Cape Town

Mbeki, M., 2009, Architects of poverty: Why African capitalism needs changing, Picador Africa, Johannesburg.

Nel, H.J., 1997, Affirmative action at local government level, The Institute for Social and Systemic Change, University of Port Elizabeth, Port Elizabeth.

Nelen, S. \& Hondeghem, A., 2000, Equality oriented personnel policy in the public sector, Instituut Voor de Overheid (IOS) Press, Amsterdam.Nelson Mandela Bay Metropolitan Municipality Draft Integrated Development Plan 2011-2016, 12 th edn., 2013/14 Financial Year, Nelson Mandela Bay Metropolitan Municipality, Port Elizabeth.

Nelson Mandela Bay Metropolitan Municipality, n.d., Nelson Mandela Bay Metropolitan Municipality Employment Equity Plan: March 2002/2006, Nelson Mandela Bay Metropolitan Municipality: Port Elizabeth | Uitenhage | Dispatch, Port Elizabeth, viewed n.d., from http://www.nelsonmandelabay.gov.za/ datarepository/documents/Kfuid_NMBM\%20Equity\%20plan.pdf.

Nelson Mandela Metropolitan Municipality, 2007, Gender and woman empowerment policy document, Nelson Mandela Bay Metropolitan Municipality, Port Elizabeth.

Nkoma, S.M. \& Stewart, M.S., 2006, Diverse entities in organisation in handbook of organisation studies, Sage, London.

Ospina, S., 2001, 'Managing diversity in civil service: A conceptual framework for public organisation', Paper presented at the United Nations expert group meeting on managing diversity in the civil service, pp. 1-19, United Nation Headquarters, New York, viewed 23 September 2014, from www.UPAN.org/ analytical.report.asp

Pesonen, S., Tienari, J. \& Vanhala, S., 2009, 'The boardroom gender paradox', Gender in Management 24(5), 327-345. http://doi.org/10.1108/17542410910968797

Policy Document for People with Disability in the Nelson Mandela Metropolitan Municipality (Incorporating the Metro Integrated Disability Strategy), March 2007, Nelson Mandela Bay Metropolitan Municipality, Port Elizabeth.

Pottinger, B., 2008, The Mbeki Legacy, Zebra Press, Cape Town.

Reichenberg, N.E., 2001, United nations expert group meeting on managing diversity in the civil service, viewed 30 July 2014, from www.http://unpan1.un.org.

Republic of South Africa, 1997, White paper on human resource management in the public service, Government Printers, Pretoria.

Republic of South Africa, 1998a, Employment Equity Act, 1998, Government Printers, Pretoria.

Republic of South Africa, 1998b, A Conceptual Framework for Affirmative Action and the Management of Diversity in the Public Service, Green Paper, Department of Public Service and Administration, Pretoria.

Shonhiwa, S., 2006, The effective cross-cultural manager: A guide for business leaders in Africa, Zebra Publishing, Cape Town.

Smit, P.J., Brevis, T., Cronje, G. \& Vrba, M.J., 2007, Management principles: A contemporary edition for Africa, Juta, Cape Town.

Smit, P.J. \& Cronje, G.J., 2002, Managing principles: A contemporary edition for Africa, 3rd edn., Juta, Cape Town.

Squires, K., 2008, Literacy of expertise: Handbook of research in new literacies, Taylor and Francis, New York.

Stockdale, M.S. \& Crosby, F.J., 2004, The psychology and management of workplace diversity, Blackwell, Oxford.

Swanepoel, B.J., Erasmus, B.J. \& Schenk, H.W., 2008, South African human resource management, 4th edn., Juta, Cape Town. 
Teifel, H.H., 1995, Corporate culture: A potential hurdle to total quality management, RAU, Johannesburg.

Thomas, R.R. Jr, 2006, Building on the promise of diversity: How we can move to the next level in our workplaces, our communities, and our society, Amacom, New York.

Van der Walt, G. \& Du Toit, D.F.P., 1997, Managing for excellence in the public sector Juta, Cape Town.
Van Dijk, H.G., 2008, 'The talent management approach to human resource management: Attracting and retaining the right people', Journal of Public Administration 43(3.1), 385-395.

Wessels, J.S., 2005, Equal employment opportunities: A conceptual puzzle', Politeid 24(2), 125-141.

Wissink, H., Schwella, E. \& Fox, W., 2004, Public management, Juta, Cape Town. 